\title{
THE RELIGIOUS EDUCATION AND THE EMOTIONAL INTELLIGENCE
}

\author{
Carmen Maria CHISIU, Ph.D., \\ „L. Blaga" University from Sibiu \\ carmenmariachisiu@yahoo.com
}

Love, the will of conception, order and consciousness of duty, all these have

to master in a family. Not the pleasure but pure joy, made by the beauty of common ideal. Petre Țuţea

\begin{abstract}
Religious education gives sap to the desire, to ability and responsibility of self-improvement. The educated man in a religious way or the emotionally intelligent man finds his way to complete his person as well emotionally, intellectually, morally, aestheticaly, physically and professionally. It is not easy but it's worth the effort to help those towards whom we have the responsibility to educate, to pave their way for understanding and make peace with themselves, with others and with Providence, no matter how, through Christian education, through religion classes or through an education according to the theory of emotional intelligence.
\end{abstract}

Keywords: religious education, emotional intelligence, art of education, psychopedagigical principles of christinity

\section{Education, an art}

For years, we have been going through a reform in education. A real, genuine and effective reform should start with educating the educators (teachers and parents) and the renewal of the art of education.

Children nowadays are different because the world is different. As a teacher, a parent, an educator could stand in front of them with authority he must have personal value. In other words to have a complex personality, harmonious, to be a scholar, a professional, a man of high professional personal morality. Only the personal value resulting from the above features make out of the educator an educational authority loved and followed, a 
stimulator for the man to become a human. If the teacher is well prepared in his field, he does his job consistently but he is blasé and permanently dissatisfied, he does not love his students, he is not himself Christianly educated or emotionally intelligent, does not mean much for his students; he cannot be the role model of perseverance, responsibility, tolerance, of peace lived and poured out, of love for his students.

Here lies the great mistake: in school, alongside education for science, it is also necessary education as an art. Science requires accuracy and truth, art implies spiritual beauty, love, understanding, inspiration, originality and creativity, these are all the ingredients that make the educator being obeyed and followed.

The renewal of art of education does not mean upgrading or other computerized methods nor to let everything to the child's choice, to tell him he is right in everything he does. The renewal of art education means a real understanding and respect for the child, his stages of development, knowing his soul-spiritual needs, respect for his freedom, granting understanding, tolerance, the empathy he needs; it means jumping from transmitting information to a learning built on communication and full involvement. Art means to achieve school learning that can be taken beyond school and house walls. A learning based on an open relationship, on communication, the discussions at the expense of what was learned, on expressing personal opinions on putting into practice what was learned at school in real contexts. It is common today to meet suffering souls, with many internal problems, who do not know how to relate to life and keep repeating the question: What should I do? What does life want from me? Torn apart souls, people that start many things and do not finish anything and always remain dissatisfied. People with problems are becoming more and more. Why? It is alack of education. The way we educate our children do not inculcate forces that make the man powerful in life. What makes man have problems, is what he lacks, because he hasn't found in himself at certain ages of childhood, adolescence and youth, forces that cannot be awakened later that is an irreversible harm.

Focusing on the acquisition of information leads to one-sided education, addressing only to the intellect, which is the minor part, just a support manifestation of the human being. The excess of information at an early age, when the child does not yet have the ability to judge logically, leads to a dogmatic thinking, it dries the soul. The race of 4-6 subjects on a daily basis, if continued in a more diluted form of educational activity, by preparing the homework, destroys the ability to listen to and to concentrate, decreases ability to memorise, there is installed a shallow breath and a weakening of the lungs, of the will and of life forces. 
Education, as it happens nowadays, makes us forget that first of all we need to learn inorder to be human.

Pedagogy and school are one step behind the development and the needs of society. And, who can say exactly how will the world of tomorrow be, how will work the society of our children and grandchildren?

On the other hand we live in an era that requires retraining every five years, which can be achieved only with a man that in school acquired skills and not information that can be found on Google.

The optimal solution is educating, training a free and open-minded person, with a vivid thinking, motivated, active, creative that is able to cope with any changes. As statements, it is the educational ideal expressed in the Education Act.

The problem persists on how this ideal is put into practice, both existing problem in education that gives school and most of the parents.

Everyone will have to learn to live for the joy of being, for love, kindness, empathy, positive emotions.

Teachers often complain that attitudes practiced in school are not valued in the family. Parenting is an honor but also a responsibility. When a man wants to drive a car he must learn first. He attends school, passes an exam and gets a driving licence. But the parent? Who teaches him? Who gives him a parent certificate? Strange, isn't it? The child is our future, as a civilization we should show responsibility towards our future!

Usually, the parent is often very unprepared and unfit for this role, which he wants very much, decided not to make the mistakes that were made to him. It is not only his fault that he is not ready for being a parent. Largely, it is the fault of society. And lately there have been started various programs to educate parents. Some parents have the willingness to inform themselves and learn about their child's education, motivated by the love for his child and the increasing number of difficult situations that arise.

Education is a way to ourselves rather than a way for the educated. Paradoxically, apparently, real education is actually a self-education. Knowing yourself you know the others, educating yourself, you become able to educate. Teachers and parents, we all need to learn to make an art out of education which children could live.

Real education makes a man human, connecting with himself, with the society, with the world, with the spiritual and leading him towards that spiritual development which is his own and necessary.

The difference between a boring teacher and one loved by children is made by a real knowledge of human life seen and accepted entirely, the passion with which we do our activity as an educator, a passion determined by the degree of development of Christian living or of emotional intelligence. 


\section{A history and theoretical aspects of emotional intelligence theory}

Instruction and religious education predispose us and train us in a greater measure to accept and understand the person next to us. Only if we have also a religious education and if we situate well in the religion area, we become more generous with others, we are no longer suspicious and we do not see the others as virtual "dangers". Only the one who doubts his faith flees from the other, isolates himself and blames the other. When students incorporate specific values and experience faith, they reach the empathic capacity necessary to understand the faith of the other, to respect honestly the diversity of religion, to open himself to the other, to offer himself and to really value him. Dialogue, authentic and constructive communication is made between people religiously educated, trained sufficiently, informed regarding their own religion and other religions or denominations.

Being religiously educated or emotionally intelligent means being educated to start towards self-becoming and educating himself through others and the others through himself.

The concern for the study and research in this field has as its starting point the reality observed by each of us and proven by professionals that many people with very good school results, with a high IQ or a well-developed academic intelligence copes less well in daily life, while another category of subjects, although with poor school results, with a low IQ compared to the first category, they have outstanding achievements. Therefore this question was asked: How do the latter manage to cope with difficult life circumstances?

Many psychologists have realized that the ability to ensure success in everyday life is different from the academic intelligence, it is a kind of sensitivity specific to personal needs, to human relationships. Thus was born the new concept of emotional intelligence.

Studies on emotional intelligence are relatively new, starting around the 90s, when the family and the society has lost sight of formation in the area of human relations. The best representative is considered to be Daniel Goleman by his book EmotionalIntelligence, published and republished by various publishing houses.

Although this term is relatively new, emerged as a concern of psychology, of education when the lack of Christian education began to be felt, components of emotional intelligence were raised in the statements of Socrates (470-399 BC ) "Know yourself!". In the holy book, both the Old and New Testaments "Do not do to another what you do not like!" And "Love your neighbor as you love yourself!" These exhortations, merely propose a manifestation of components of emotional intelligence. 
Emotional intelligence is a construction of several elements: self-knowledge, understanding our own emotions, managing efficiently our own emotions and the significantly increase of life quality, a better understanding of the others and the living with a high degree of comfort, creating better relations at all levels with the others and the increase of personal productivity.

In life, according to statistical surveys, the emotional competence is at least as important as are professional skills.

Developing emotional intelligence requires a long-term practice of the capacity of understanding and managing our own emotions and those of others, to create harmoniousrelations yourself, with others and with the providence, as a manifestation of love towards our neighbour.

In order to succeed in life Goleman believes that each of us should learn and practice the main dimensions of emotional intelligence. Adults, teachers and parents will be able to develop emotional and social potential of children, teaching them to adopt and develop emotional intelligence features, involving them in a permanent training activity by helping them:

- to identify and differentiate their personal experiences;

- to learn more about how and where they can externalize feelings;

- to develop their empathy - the ability to put feelings into line with the needs of others;

-to read body language and other nonverbal aspects in order to achieve better communication and understanding the needs of others;

- to learn to listen to opinions, desires and needs of others;

- to learn to be constructive, positive, open in the relation with others.

All these ways of expression of love towards our neighbour, expressed in a psychological language, we may call them manifestations of emotional intelligence.

In a dynamic world, in a continuous changing, as the one we live, we need individuals trained to adapt quickly, almost instinctively but constructive and positive to unforeseen situations, that is individuals who beyond academic intelligence, beyond the good training, would be adequately prepared to face the moral challenges, according to the principles preached by Christianity.

\section{A comparative analysis of the emotional intelligence components and the psychopedagigical principles of christinity}

Emotionally intelligent people enjoy: good relations with others, compassion for others, reconciliation with themselves, self-motivation, performance enhanced at work, increased motivation, proactive attitude, initiative, selfconfidence and confidence in others, an effective management of their own 
life and of their own resources, availability and great ability to work with others.

Emotional intelligence components describe attitudes that match perfectly over what concerns psychopedagogical principles of the Holy Three Hierarchs.

Making a comparison, Table 1, it is easy to see that the objectives to which the two approaches are oriented are the same - the education of man with himself, with the others and with the Providence, responsible and involved in the activity according to the age.

Table 1

\begin{tabular}{|l|l|}
\hline $\begin{array}{l}\text { Components of } \\
\text { emotional } \\
\text { intelligence }\end{array}$ & Pedagogical principles of Christianity \\
\hline $\begin{array}{l}\text { Effective } \\
\text { management of own } \\
\text { emotions and the } \\
\text { significant increase } \\
\text { of the quality of life; }\end{array}$ & $\begin{array}{l}\text { "When a house is not well managed and there } \\
\text { bovern nerves, screams, insults ... then all these } \\
\text { Great Interpretation to Psalm 28 }\end{array}$ \\
\hline $\begin{array}{l}\text { A better } \\
\text { understanding of } \\
\text { others and living with } \\
\text { a high degree of } \\
\text { comfort; }\end{array}$ & $\begin{array}{l}\text { "You should love your neighbour as you love } \\
\text { yourself" New Testament, Matthew 22: 36-40 }\end{array}$ \\
\hline $\begin{array}{l}\text { Creating better } \\
\text { relationships at all } \\
\text { levels with others and } \\
\text { the increase personal } \\
\text { productivity. }\end{array}$ & $\begin{array}{l}\text { "All that you want to be made to you by others, } \\
\text { Matthew 7:12 it to them" New Testament, } \\
\text { result. Father's kindness restrains the children, } \\
\text { while his pride creates guts and impertinence ". } \\
\text { St. Gregory the Theologian, Poems for others, } \\
\text { The Poem. }\end{array}$ \\
\hline
\end{tabular}

Analysing, we can say that the emotionally intelligent teacher, does nothing but to follow pedagogical principles stated by the Three Hierarchs and the postulates of Old and New Testaments.

And if in school there are children from Christian families or belonging to other religions, agnostics or atheists, the purpose of the school is to train balanced, responsible, loving individuals. It is necessary to find the way to achieve the goal; following the principles of Christianity or of emotional intelligence theory, where religion is denied. 


\section{References}

Chisiu, C., M. Parents school, Ed. University,, L. Blaga, Sibiu, 2015.

Cucos, C. Religious Education. Theoretical and methodological references, Polirom, Iasi, 2009.

Goleman, D., Emotional Intelligence, Humanitas, Bucharest, 2005.

Steiner, R. Education, a social problem, Ed. Biodin, Bucharest, 2006.

Stylianakis Abbot, A., I., Pedagogical principles of the Three Saints hierarchy can be applied even today, Ed. Ecumenical, Galati, 2012. 